\title{
PENGEMBANGAN PERANGKAT PEMBELAJARAN MENGGUNAKAN PENDEKATAN SAINTIFIK BERBANTUAN GEOGEBRA PADA MATERI GARIS SINGGUNG PERSEKUTUAN DUA LINGKARAN UNTUK KELAS VIII SMP
}

\author{
Saniaturochmah \\ Program Studi Pendidikan Matematika, Jurusan Matematika, FMIPA, Universitas Negeri Surabaya \\ $e$-mail: saniaturochmahsaniaturochmah16030174098@mhs.unesa.ac.id \\ Ika Kurniasari \\ Program Studi Pendidikan Matematika, Jurusan Matematika, FMIPA, Universitas Negeri Surabaya \\ $e$-mail: Ikakurniasari@unesa.ac.id
}

\begin{abstract}
Abstrak
Tujuan dari penelitian ini adalah untuk mendeskripsikan proses dan hasil pengembangan perangkat pembelajaran menggunakan pendekatan saintifik berbantuan GeoGebra pada materi garis singgung persekutuan dua lingkaran untuk kelas VIII SMP yang memenuhi krtieria valid, praktis dan efektif. Proses pengembangan pada penelitian ini menggunakan tahapan-tahapan pengembangan model Plomp (2010) mencakup tahap penelitian awal (preliminary research) yang dilakukan dengan analisis kebutuhan peserta didik dan analisis materi, tahap selanjutnya adalah pembuatan prototipe (prototyping) yaitu dilakukan dengan menyusun perangkat pembelajaran sesuai dengan hasil analisis pada tahap sebelumnya sedangkan tahap terakhir adalah penilaian (assessment) yang dilakukan dengan ujicoba hasil pengembangan perangkat pembelajaran. Adapun perangkat pembelajaran yang dikembangkan berupa Silabus, Rencana Pelaksanaan Pembelajaran (RPP) dan Lembar Kerja Peserta didik (LKPD). Berdasarkan hasil validasi maka perangkat pembelajaran memenuhi kriteria kevalidan dengan $V R_{\text {silabus }}$ sebesar 3,23 maka Silabus dikatakan valid, $V R_{R P P}$ sebesar 3,43 maka RPP dikatakan sangat valid dan $V R_{L K P D}$ sebesar 3,22 maka LKPD dikatakan valid. Berdasarkan hasil pengamatan terhadap keterlaksanaan pembelajaran, maka perangkat pembelajaran memenuhi kriteria kepraktisan pada pertemuan satu menghasilkan skor sebesar 3,78 dan pada pertemuan dua sebesar 3,92 yang termasuk pada kategori sangat baik. Kriteria keefektifan terpenuhi berdasarkan hasil respon peserta didik yang termasuk pada kategori positif yaitu sebesar $85,2 \%$ dan berdasarkan hasil tes peserta didik dengan perolehan persentase ketuntasan belajar klasikal pada kategori tinggi yaitu sebesar 81,25\%. Diperoleh kesimpulan dari hasil analisis data tersebut, bahwa perangkat pembelajaran menggunakan pendekatan saintifik berbantuan GeoGebra pada materi garis singgung persekutuan dua lingkaran untuk kelas VIII SMP memenuhi kriteria valid, praktis dan efektif.
\end{abstract}

Kata Kunci: perangkat pembelajaran, pendekatan saintifik, GeoGebra, garis singgung persekutuan dua lingkaran.

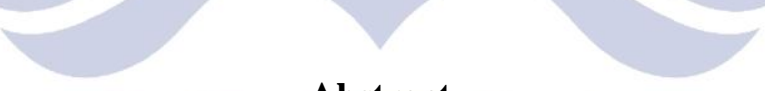

\begin{abstract}
The aims of this research is to describe the process and outcomes of the development of learning equipment using the GeoGebra-assisted with scientific approach for common tangent of to two circles on 8th grade junior high school which is valid, practical, and effective. The process of developing learning equipment in this research use the Plomp model (2010) consisting of preliminary research phase by analyzing students' needs and material analyzing, the second phase is prototyping that arranging learning equipment based of the result from the previous anlysis and the last phase is assessment by testing the result of the development of learning equipment. The learning equipment developed are Syllabus, Lesson Plan and Student Worksheet. Based on the results of the validation, the learning equipment meets the validity criteria with $V R_{\text {syllabus }}$ is 3,23 then the Syllabus is valid, $V R_{R P P}$ is 3,43 then the Lesson Plan is very valid and $V R_{L K P D}$ is 3,22 then Student Worksheet is valid. The learning equipment meets the practicality criteria based on observations implementation with average score on the first day is 3,78 and the second day is 3,92 which is included in the excellent category. The effectiveness criteria are meets based on the results of the students' responses in the positive category is $85,2 \%$ and the results of the student learning test with the percentage of students completing classical learning in the high category is $81,25 \%$. Based on the results of the analysis of these data, the result of this research is that the learning equipment using the GeoGebra-assisted scientific approach for common tangent of to two circles on 8th grade junior high school fullfilled the criteria of valid, practical and effective.
\end{abstract}

Keywords: learning equipment, scientific approach, GeoGebra, common tangent of to two circle. 


\section{PENDAHULUAN}

Keberhasilan peserta didik dalam mendapatkan pengetahuan baru merupakan salah satu tugas guru. Guru berperan penting dalam upaya melaksanakan pembelajaran dengan baik agar tujuan pembelajaran tercapai. Bukan hanya sekedar menyampaikan pengetahuan, guru sebagai fasilitator bertugas untuk memfasilitasi peserta didik agar mampu mengembangkan kemampuan berpikirnya sehingga suatu konsep dapat dipahami. Guru yang mempunyai kemampuan dalam mengembangkan dan mengelola pembelajaran dengan baik dapat memberikan kemudahan bagi peserta didik selama proses pembelajarannya sehingga kompetensi peserta didik terbentuk.

Menurut Sanjaya (2017) guru yang profesional mempunyai tiga peran penting agar pembelajaran berjalan efektif, yaitu sebagai seorang perancang pembelajaran yang mengatur segala persiapan yang dibutuhkan, sebagai penyelenggara yang menerapkan proses belajar yang telah disusun, dan terakhir adalah sebagai evaluator yang menganalisis tingkat keberhasilan pembelajarannya. Guru dalam merencanakan pembelajaran tentunya perlu menyiapkan hal-hal yang dibutuhkan peserta didik terkait dengan pembelajaran dan tidak terlepas dari kurikulum yang berlaku. Oleh sebab itu, guru perlu mengatur persiapan apa saja yang dibutuhkan peserta didik terkait dengan pembelajaran seperti mempersiapkan perangkat pembelajaran. Hal ini menyebabkan guru untuk terus berinovasi dalam menciptakan pembelajaran yang efektif dalam upaya membantu proses pemahaman peserta didik sehingga tercapainya suatu keberhasilan dalam proses belajar. Mengembangkan suatu perangkat pembelajaran dapat menjadi salah satu cara bagi guru untuk berinovasi dengan tetap memperhatikan karakteristik dan kebutuhan peserta didiknya. Adanya perangkat pembelajaran, dapat memberikan panduan kepada guru agar selama proses pembelajaran berjalan secara sistematis dan efektif.

Guru ketika mengembangkan perangkat pembelajaran tidak terlepas dari kurikulum yang berlaku, hal ini dapat dilihat dalam Permendikbud No. 81A Tahun 2013 tentang implementasi kurikulum. Saat ini pendidikan di Indonesia sedang menggunakan Kurikulum 2013 (K-13). Dalam Kurikulum 2013 guru perlu merencanakan pembelajaran dimana peserta didik diberi kesempatan untuk memperoleh pengetahuannya secara mandiri dan kreatif. Pengetahuan peserta didik yang diperoleh berdasarkan pengalaman sendiri cenderung lebih bermakna. Permendikbud No. 103 Tahun 2014 menyatakan bahwa pembelajaran yang ada pada Kurikulum 2013 menggunakan pendekatan saintifik atau pendekatan berbasis ilmiah. Pendekatan saintifik adalah pendekatan yang mecakup tahapan-tahapan ilmiah selama proses pembelajaran di antaranya mengamati, menanya, mencoba/ mengumpulkan informasi, menalar/ mengasosiasi/ mengolah informasi, dan mengkomunikasikan. Pendekatan saintifik dipercaya mampu menciptakan karakter peserta didik yang mandiri dan kreatif dalam memecahkan suatu permasalahan.

Salah satu prinsip Kurikulum 2013 menyatakan bahwa selama pembelajaran di kelas hendaknya penggunaan teknologi dapat digunakan semaksimal mungkin untuk meningkatkan keefektifan dan keefisienan pembelajaran. Perkembangan teknologi ini tentunya berpengaruh pada dunia pendidikan, sehingga guru diharuskan untuk dapat memanfaatkan berbagai macam teknologi sebagai alat bantu selama proses pembelajaran. Adanya teknologi menjadikan aktivitas dalam memperoleh informasi maupun untuk melakukan proses belajar memiliki dampak yang luas. Salah satunya dampak dalam pembelajaran menurut Pribadi (2017) yaitu terjadi perubahan paradigma pembelajaran karena adanya kemajuan teknologi ini. Paradigma sebelumnya guru dianggap menjadi sumber ilmu satu-satunya bagi peserta didik dalam menyampaikan materi sehingga semua pengetahuan bersumber dari guru. Namun, dengan adanya kemajuan teknologi mengubah paradigma tersebut menjadikan informasi yang dibutuhkan peserta didik dapat dicari melalui berbagai sumber bukan hanya dari guru. Saat ini, guru tidak selalu berperan menjadi satu-satunya sumber pengetahuan namun guru berperan penting dalam mengelola dan mengembangkan pembelajaran dengan memanfaatkan teknologi ini. Dengan mengorientasikan pembelajaran dengan pemanfaatan teknologi ini diharapkan mampu memudahkan peserta didik selama proses belajarnya. Penggunaan teknologi selama proses pembelajaran ini juga bertujuan untuk mengurangi kesulitan belajar yang disebabkan oleh abstraknya objek dalam matematika. Selain itu, pembelajaran dalam kelas tidak sekedar dilakukan dengan penggunaan teknologi saja namun juga perlu dikombinasikan dengan perangkat pembelajaran yang sesuai dengan aturan Kurikulum yang berlaku. Dengan kondisi yang demikian memungkinkan adanya pembelajaran yang sudah terhubung dengan teknologi.

Salah satu hal dalam pembelajaran di kelas yang dapat diintegrasikan dengan teknologi adalah penggunaan media pembelajaran. Teknologi yang dirancang dan dikembangkan dengan baik dapat digunakan menjadi media pembelajaran untuk menyampaikan pengetahuan menjadi menarik dan jelas. Hal ini membuat kualitas pembelajaran meningkat yang berdampak pula pada pencapaian kemampuan peserta didik. Adanya media pembelajaran berbasis teknologi saat ini tidaklah sedikit, berbagai macam inovasi yang terkait terus bertambah. Hal ini menunjukan bahwa teknologi sudah mencapai dunia pendidikan dan dapat dimanfaatkan dengan sebaikbaiknya. Salah satu contohnya adalah GeoGebra. GeoGebra merupakan aplikasi yang dapat digunakan 
peserta didik untuk meningkatkan pemahaman konsep matematika mengenai geometri dan aljabar. Aplikasi GeoGebra dapat diunduh melalui smartphone dan komputer ataupun di akses melalui website resminya yaitu www.geogebra.org secara gratis.

Sehubungan dengan hal tersebut, GeoGebra dapat digunakan oleh peserta didik untuk memahami materi Garis Singgung Persekutuan Dua Lingkaran. Materi ini termasuk dalam bab Lingkaran yang merupakan salah satu materi yang berkaitan dengan geometri pada jenjang pendidikan SMP. Peserta didik ketika memahami objek geometri yang abstrak selama pembelajaran dapat memanfaatkan alat bantu GeoGebra. Dengan adanya GeoGebra dapat menampilkan ilustrasi terkait dengan geometri khususnya materi ini. Dengan begitu, peserta didik dapat memperoleh pengetahuan baru berdasarkan langkah-langkah ilmiah dengan berbantuan GeoGebra.

Berdasarkan uraian di atas, pertanyaan penelitian ini adalah bagaimanakah proses dan hasil pengembangan perangkat pembelajaran menggunakan pendekatan saintifik berbantuan GeoGebra pada materi garis singgung persekutuan dua lingkaran yang memenuhi kriteria valid, praktis dan efektif.

Sedangkan penelitian ini memiliki tujuan untuk mendeskripsikan proses dan hasil pengembangan perangkat pembelajaran menggunakan pendekatan saintifik berbantuan GeoGebra pada materi garis singgung persekutuan dua lingkaran yang memenuhi kriteria valid, praktis dan efektif.

\section{Pendekatan Saintifik}

Menurut Rusman (2017), pendekatan saintifik adalah suatu pendekatan dalam pembelajaran dimana selama prosesnya menekankan peserta didik pada kegiatan mengamati, menanya, menalar, mencoba dan mengkomunikasikan. Sedangkan menurut Maryani dan Fatmawati (2015) pendekatan saintifik adalah pendekatan yang mengarahkan peserta didik melalui kegiatan mengenal, memahami beberapa materi ajar dengan menggunakan pendekatan berbasis ilmiah, dimana informasi tersebut memungkinkan bersumber dari manapun, kapanpun dan tidak selalu berdasarkan pada penjelasan yang diberikan oleh guru.

Berdasarkan beberapa pendapat yang telah dikemukakan, maka pendekatan saintifik adalah pendekatan yang memfokuskan pada proses pembelajaran menggunakan langkah-langkah berbasis ilmiah seperti mengamati, menanya, mencoba, menalar dan mengkomunikasikan. Hal ini bertujuan agar peserta didik lebih berperan dalam menemukan informasi bukan hanya dari guru namun informasi dapat dicari dari beragam sumber.
Pada Lampiran IV Permendikbud No. 81A Tahun 2013 dijelaskan bahwa pendekatan saintifik meliputi lima langkah pembelajaran yaitu mengamati, menanya, mencoba, mengolah informasi dan mengkomunikasikan. Berikut deskripsi dari langkah pembelajaran tersebut:

1. Mengamati

Dalam kegiatan ini guru memberikan peluang kepada peserta didik untuk melakukan beberapa kegiatan pengamatan secara lebih luas seperti melihat, membaca, menyimak dan mendengar dari suatu permasalahan.

2. Menanya

Selanjutnya kesempatan untuk mengajukan pertanyaan dapat dilakukan oleh peserta didik terkait dengan hasil pengamatan yang telah dilakukan peserta didik pada tahap sebelumnya.

3. Mencoba

Dari berbagai macam sumber dan cara yang dilakukan peserta didik mulai mencari dan menemukan informasi. Dari kegiatan tersebut terkumpul sejumlah informasi yang selanjutnya digunakan untuk menjawab terkait permasalahan yang diberikan.

4. Mengolah Informasi

Pada kegiatan ini, beberapa informasi telah diperoleh dari kegiatan sebelumnya yang dapat dijadikan dasar dalam memroses informasi untuk dicari keterkaitan antar informasi lainnya sampai didapatkan suatu kesimpulan.

5. Mengkomunikasikan

Selanjutnya peserta didik menuliskan kesimpulan yang telah diperoleh setelah melalui beberapa kegiatan tersebut. Hasil yang telah dibuat kemudian disampaikan atau dipresentasikan di depan kelas dan oleh guru diberi nilai dan digunakan sebagai hasil belajar individu atau kelompok.

\section{Perangkat Pembelajaran}

Menurut Akbar (2012) perangkat pembelajaran dapat diartikan sebagai sejumlah alat, bahan, petunjuk, media dan pedoman yang selanjutnya akan diterapkan oleh guru selama proses pembelajaran. Sedangkan Zuhdan, dkk (2011) menyatakan bahwa perangkat pembelajaran ialah suatu perlengkapan atau alat yang digunakan untuk melangsungkan proses yang melibatkan guru dan peserta didik dalam melakukan aktivitas pembelajaran.

Berdasarkan pendapat yang telah dikemukakan oleh Akbar dan Zuhdan, dapat ditarik kesimpulan mengenai perangkat pembelajaran yaitu segala peralatan atau perlengkapan yang dirancang dan digunakan oleh guru sebagai panduan selama proses pembelajaran. Perangkat pembelajaran dapat mencakup Silabus, Rencana Pelaksanaan Pembelajaran (RPP), Lembar Kerja Peserta 
didik (LKPD), materi, instrumen penilaian dan panduan pembelajaran (Widaningsih, 2019).

\section{GeoGebra}

GeoGebra diciptakan pada tahun 2001 oleh Markus Hohenwarter. Menurut Hohenwarter (2008) GeoGebra adalah program komputer yang dimanfaatkan untuk membelajarkan matematika khususnya terkait dengan geometri dan aljabar. Software ini dapat digunakan secara gratis melalui seluruh platform digital dan dapat diunduh dari situs aslinya yaitu www.geogebra.org. Sedangkan dalam situsnya, GeoGebra dijelaskan sebagai program matematika dinamis yang dapat digunakan oleh semua jenjang pendidikan dimana program ini mengajarkan berbagai materi geometri, statistik, grafik, aljabar dan kalkulus yang telah dirancang agar mudah untuk digunakan. GeoGebra secara khusus dibuat untuk dapat menampilkan banyak representasi dari suatu objek dinamis sekaligus. Hal ini yang dapat menjadikan GeoGebra sebagai media pembelajaran yang tepat pada pembelajaran matematika.

\section{Kriteria Perangkat Pembelajaran Yang Baik}

Menurut Nieveen (1999) ketika melakukan penelitian pengembangan, kualitas suatu perangkat pembelajaran menekankan pada tiga kriteria yaitu kevalidan (validity), kepraktisan (practicality), dan keefektifan (effectiveness). 1. Kevalidan (validity)

Menurut Nieveen pada aspek ini mengacu pada sejauh mana komponen didasarkan pada pengetahuan yang benar dan sejauh mana berbagai komponen dalam produk yang dikembangkan memiliki keterkaitan.

2. Kepraktisan (particality)

Sedangkan aspek kepraktisan menurut Nieveen mengacu pada pernyataan para ahli terkait kelayakan produk yang selanjutnya akan diterapkan dan bagaimana penerapan secara lebih jelas di lapangan terhadap produk yang dikembangkan.

3. Keefektifan (effectiveness)

Selanjutnya mengenai aspek keefektifan, menurut Nieveen mengacu pada pendapat dari pengguna produk tersebut dan apakah penggunaan produk tersebut sesuai dengan tujuan yang dimaksudkan. Jika produk yang dikembangkan memenuhi tercapainya suatu tujuan pembelajaran maka produk tersebut efektif.

\section{Model Pengembangan Plomp}

Beberapa penelitian pengembangan menggunakan penelitian pengembangan model Plomp. Model Plomp secara umum digunakan untuk penelitian pengembangan yang berkaitan dengan dunia pendidikan. Tahapantahapan penelitian pengembangan model Plomp (2010) meliputi tahapan preliminary research, prototyping, assessment.

1. Penelitian Awal (preliminary research)

Kegiatan awal yang dilakukan dalam tahapan ini dapat berupa tinjauan literatur dan proyek, serta menjawab pertanyaan yang berkaitan dengan penelitian yang akan dilakukan. Hasilnya akan digunakan sebagai pedoman untuk melanjutkan ke tahapan selanjutnya.

2. Pembuatan Prototipe (prototyping)

Selanjutnya, pada tahap ini dilakukan pengembangkan prototipe sesuai dengan urutannya yang nantinya akan direvisi dan diujicoba pada tahapan penilaian. Prototipe yang telah dikembangkan selanjutnya dinilai oleh ahli.

3. Penilaian (assessment)

Kegiatan yang dilakukan ialah melakukan evaluasi terkait para pengguna produk ini dapat menggunakannya dengan baik dan bersedia menerapkannya dalam pengajaran mereka (relevansi \& keberlanjutan).

\section{METODE}

Penelitian ini tergolong sebagai penelitian pengembangan, karena mengembangkan suatu produk berupa perangkat pembelajaran. Adapun perangkat pembelajaran yang dikembangkan ialah Silabus, RPP dan LKPD. Model Plomp (2010) diterapkan dalam proses pengembangan ini karena model tersebut digunakan pada pengembangan di bidang pendidikan termasuk perangkat pembelajaran. Tahapan Plomp dapat dilihat pada Gambar 1 mencakup tahap penelitian awal, pembuatan prototipe dan penilaian.

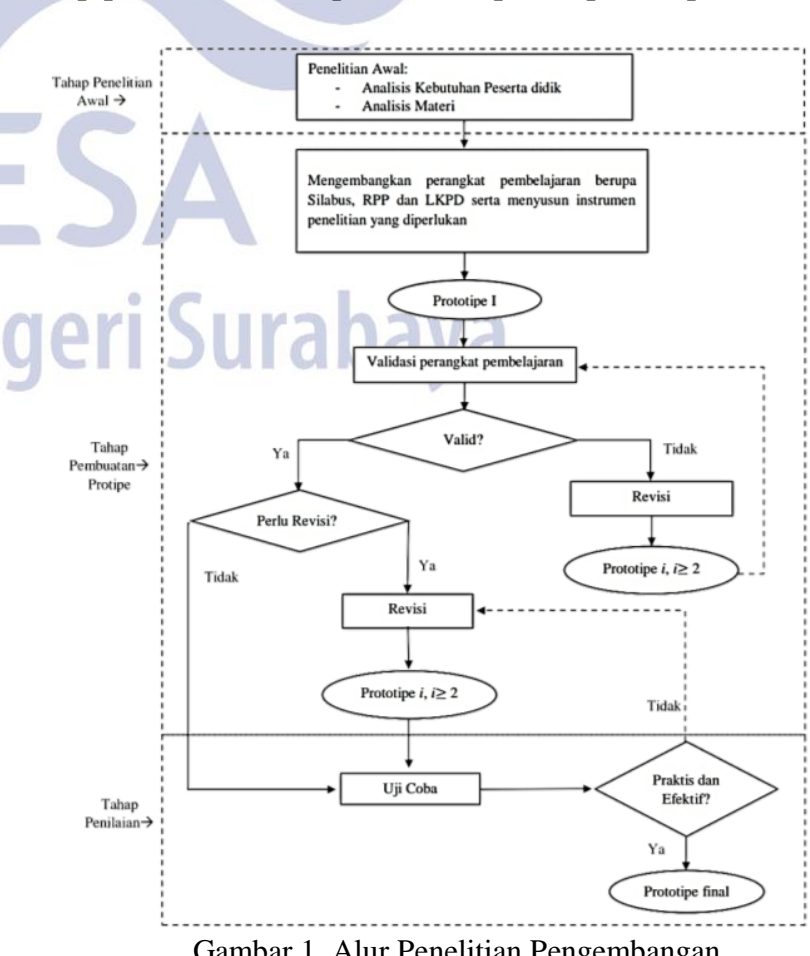

Gambar 1. Alur Penelitian Pengembangan 
Keterangan:

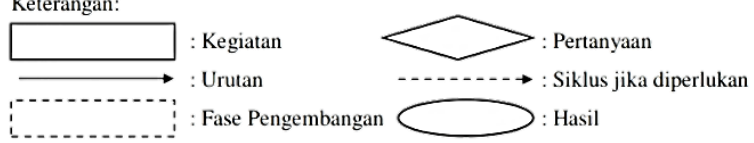

Pada tahap penelitian awal peneliti melaksanakan kegiatan untuk memahami persoalan awal yaitu dengan analisis materi dan analisis kebutuhan. Analisis materi dilakukan melalui kegiatan menelaah KD dalam Permendikbud terkait materi yang dipilih guna untuk menyusun pokok bahasan beserta indikator. Analisis kebutuhan melalui kegiatan mencari informasi terkait dengan kebutuhan peserta didik seperti informasi terkait selama proses pembelajaran. Data yang diperoleh bersumber dari informasi yang disampaikan oleh guru maupun peserta didik. Informasi yang telah diterima kemudian dilanjutkan pada proses analisis untuk mendapatkan rancangan sebagai landasan mengembangkan perangkat pembelajaran.

Pada tahap pembuatan prototipe, perangkat pembelajaran mulai dikembangkan dengan memperhatikan hasil dari tahapan sebelumnya yang kemudian akan dinilai oleh validator. Sebelum diberikan kepada validator dilakukan diskusi terhadap dosen pembimbing terlebih dahulu. Jika hasil penilaian dari validator membutuhkan revisi maka dilakukan perbaikan sampai diberikan nilai valid sehingga perangkat pembelajaran dapat diujicobakan pada tahap selanjutnya.

Pada tahap penilaian dilakukan ujicoba dengan menerapkan perangkat pembelajaran pada subjek yang telah ditentukan. Penelitian ini juga melibatkan teman sejawat peneliti yang ditugaskan sebagai pelaksana dalam menerapkan perangkat pembelajaran yang dikembangkan. Selama pelaksanaanya dilakukan pengamatan proses pembelajaran dan di akhir pertemuan diberikan tes dan angket.

Penelitian ini dilaksanakan pada semester genap tahun ajaran 2019/2020 di SMPN 2 Sidoarjo. Sedangkan subjek penelitian yang digunakan yaitu kelas VIII-F sebanyak 32 peserta didik karena belum mendapatkan materi garis singgung persekutuan dua lingkaran.

Data yang diperoleh mencakup hasil lembar validasi perangkat pembelajaran, lembar pengamatan keterlaksanaan perangkat pembelajaran, tes hasil belajar, dan agket respon. Lembar validasi diberikan dengan tujuan agar memperoleh data terkait tanggapan dari para ahli yang akan menjadi validator. Hasil data yang telah diperoleh kemudian digunakan untuk menilai kevalidan. Lembar pengamatan keterlaksanaan diberikan dengan tujuan agar mendapatkan data mengenai keterlaksanaan pengajar dalam menerapkan perangkat pembelajaran. Hasil data yang telah diperoleh kemudian digunakan untuk mengukur kepraktisan. Lembar pengamatan keterlaksanaan diberikan kepada guru matematika yang bertugas sebagai pengamat selama proses pembelajaran. THB diberikan dengan tujuan untuk mendapatkan data mengenai ketuntasan belajar. Tes hasil belajar dikerjakan oleh peserta didik setelah menerima semua materi garis singgung persekutuan dua lingkaran. Tes ini dikerjakan melalui applets GeoGebra yang terdiri dari tes pilihan ganda, melukis dan uraian. Angket diperlukan untuk mendapatkan data mengenai respon dari peserta didik tentang perangkat pembelajaran yang telah diterapkan. Hasil dari data tes belajar dan angket respon yang telah diperoleh selanjtunya akan digunakan dalam mengukur keefektifan.

Analisis kevalidan diperoleh berdasarkan nilai yang diberikan oleh validator. Kemudian dihitung rata-rata validitas untuk Silabus, RPP dan LKPD. Berdasarkan perolehan skor rata-rata (VR) selanjutnya dapat di kategorikan dalam tabel di bawah untuk menentukan kevalidan:

Tabel 1. Kategori Rata-rata Total Validitas

\begin{tabular}{|c|c|}
\hline Interval Skor & Kategori \\
\hline $3,25 \leq V R_{\text {Silabus/RPP/LKPD }} \leq 4,00$ & Sangat Valid \\
\hline $2,50 \leq V R_{\text {Silabus/RPP/LKPD }}<3,25$ & Valid \\
\hline $1,75 \leq V R_{\text {Silabus/RPP/LKPD }}<2,50$ & $\begin{array}{c}\text { Kurang } \\
\text { Valid }\end{array}$ \\
\hline $1,00 \leq V R_{\text {Silabus/RPP/LKPD }}<1,75$ & Tidak Valid \\
\hline \multicolumn{2}{|c}{ (Khabibah, 2006) }
\end{tabular}

Jika hasil rata-rata validitas tergolong pada kategori sangat valid atau valid maka perangkat pembelajaran memenuhi kriteria kevalidan.

Selanjutnya, untuk menentukan kepraktisan diperoleh dari hasil pengamatan keterlaksanaan dengan menghitung rata-rata setiap pertemuannya (KP), kemudian dicocokan pada kategori berikut:

Tabel 2. Kategori Rata-rata
Keterlaksanaan Pembelajaran

Jika hasil keterlaksanaan tergolong pada kategori sangat baik atau baik maka perangkat pembelajaran memenuhi kriteria kepraktisan.

Analisis keefektifan berdasarkan hasil tes dan angket respon. Tes belajar dihitung persentase peserta didik yang tuntas dengan KKM yang telah ditetapkan sekolah. Kemudian menentukan kategori ketuntasan sebagai berikut: 
Tabel 3. Kategori Ketuntasan Peserta didik

\begin{tabular}{|c|c|}
\hline Interval Skor & Kategori \\
\hline $85 \% \leq p$ & Sangat tinggi \\
\hline $75 \% \leq p<85 \%$ & Tinggi \\
\hline $60 \% \leq p<75 \%$ & Sedang \\
\hline $40 \% \leq p<60 \%$ & Rendah \\
\hline$p<40 \%$ & Sangat rendah \\
\hline & (Depdiknas, 2003)
\end{tabular}

Jika persentase ketuntasan tergolong pada kategori sangat tinggi atau tinggi maka perangkat pembelajaran memenuhi kriteria keefektifan.

Sedangkan angket respon dihitung persentase rataratanya, kemudian ditentukan kategori pada tabel berikut:

Tabel 4. Kategori Rata-rata Respon Peserta didik

\begin{tabular}{|c|c|}
\hline Interval Skor & Kategori \\
\hline $80 \%<R S \leq 100 \%$ & Sangat Positif \\
\hline $60 \%<R S \leq 80 \%$ & Positif \\
\hline $40 \%<R S \leq 60 \%$ & Cukup Positif \\
\hline $20 \%<R S \leq 40 \%$ & Kurang Positif \\
\hline $0 \leq R S \leq 20 \%$ & Tidak Positif \\
\hline
\end{tabular}

Jika hasil angket respon tergolong pada kategori sangat positif atau positif maka perangkat pembelajaran memenuhi kriteria keefektifan.

\section{HASIL DAN PEMBAHASAN}

\section{Hasil Penelitian}

Penelitian ini menggunakan tahapan-tahapan model pengembangan model Plomp (2010). Berikut adalah deskripsi hasil dari masing-masing tahap:

1. Penelitian Awal

a. Analisis Kebutuhan Peserta Didik

Analisis ini didasarkan pada informasi yang disampaikan oleh guru maupun peserta didik. Dari informasi tersebut, diperoleh bahwa peserta didik sudah mendapatkan materi lingkaran namun pada sub materi hubungan sudut pusat - dan - sudut keliling, untuk sub materi garis singgung persekutuan dua lingkaran peserta didik belum pernah menerima materi tersebut. Selain itu, guru dalam mengajarkan materi tersebut masih menggunakan media pembelajaran konvensional, sedangkan untuk sub materi garis singgung persekutuan dua lingkaran biasanya guru tidak menggunakan media pembelajaran. Sedangkan peserta didik juga membutuhkan alat bantu dalam membayangkan objek-objek matematika khususnya dalam geometri, sehingga alat bantu yang bisa digunakan adalah yang berbasis teknologi karena sebelumnya peserta didik belum pernah menggunakan media pembelajaran berbasis teknologi dalam pelajaran matematika.

Selanjutnya, beberapa LKPD yang sebelumnya digunakan berisikan latihan-latihan soal saja sehingga LKPD yang digunakan tidak mendorong peserta didik untuk bebas dalam mengeksplorasi pengetahuannya. Hal ini juga berkaitan karena peserta didik lebih tertarik jika pembelajaran tidak berpusat pada guru karena jika mereka kurang aktif maka peserta didik cenderung mengalami kebosanan sehingga berdampak pada pemahaman peserta didik.

b. Analisis Materi

Pengembangan perangkat pembelajaran ini menggunakan materi garis singgung persekutuan dua lingkaran. Dalam Lampiran Permendikbud No. 37 Tahun 2018 dituliskan Kompetensi Dasar terkait materi garis singgug persekutuan dua lingkaran yaitu pada KD 3.8 dan 4.8. Selanjutnya dapat disusun indikator pembelajaran yang akan dicapai dari hasil penjabaran Kompetensi Dasar tersebut. Berdasarkan penjabaran KD dan indikator, diperoleh bahwa pokok bahasan materi yang akan digunakan untuk menyusun perangkat pembelajaran ini adalah pengertian garis singgung lingkaran, garis singgung persekutuan dua lingkaran, melukis garis singgung persekutuan dua lingkaran dan panjang garis singgung persekutuan dua lingkaran.

2. Pembuatan Prototipe

a. Pengembangan Perangkat Pembelajaran

Sebelum memulai mengembangkan perangkat pembelajaran, peneliti menyusun instrumen yang diperlukan kemudian didiskusikan kepada dosen pembimbing. Selanjutnya penyusunan Silabus dan RPP diawali dengan memperhatikan setiap komponennya berdasarkan aturan dalam Permendikbud. Kemudian dilanjutkan dengan menentukan banyaknya tatap muka yang dibutuhkan, untuk pembelajaran awalnya dilakukan selama 3 kali pertemuan namun diubah menjadi 2 kali pertemuan. Pertemuan pertama memiliki alokasi waktu 2 JP sedangkan pertemuan kedua adalah 3 JP. Dengan masing-masing JP adalah 40 menit. Kemudian ditambahkan satu pertemuan lagi untuk dilakukan tes dan pemberian angket respon. Silabus dan RPP disusun dengan mencantumkan langkah-langkah pendekatan saintifik pada kolom kegiatan pembelajaran. Selanjutnya, LKPD yang disusun adalah sebanyak 3 dimana LKPD 1 memuat pengenalan tentang garis singgung lingkaran, garis singgung persekutuan beserta cara melukisnya. Sedangkan 
pada LKPD 2 dan 3 memuat panjang garis singgung persekutuan luar dan dalam kedua lingkaran. Terdapat petunjuk pengerjaan untuk setiap kegiatan dalam LKPD. LKPD dikerjakan secara berkelompok terdiri dari 5-6 peserta didik yang telah dibagi oleh guru dengan kemampuan yang berbeda setiap kelompoknya. Setiap LKPD disusun dengan memuat kegiatan pendekatan saintifik. Pengerjaan LKPD diawali dengan diberikan suatu permasalahan yang harus diselesaikan dengan diskusi kelompok. Permasalahan tersebut diamati peserta didik kemudian diberikan kesempatan untuk melakukan tanya jawab terkait hasil pengamatan, pertanyaan tersebut juga dapat ditulis pada kolom yang telah disediakan pada LKPD. Selanjutnya adalah melakukan eksperimen untuk memperoleh informasi awal yang dibutuhkan karena informasi tersebut nantinya digunakan sebagai jawaban untuk menyelesaikan permasalahan. Setelah mendapatkan sejumlah informasi yang dirasa cukup untuk menyelesaikan permasalahan selanjutnya informasi tersebut diolah sampai menjadi suatu kesimpulan sebagai solusi permasalahan. Kegiatan terakhir adalah menyampaikan hasil diskusi kelompok ke depan kelas.

Dalam pengerjaan LKPD dibantu dengan applets GeoGebra. Beberapa applets telah dikembangkan oleh peneliti sesuai dengan pokok bahasan yang telah ditentukan. Applets ini dapat dibuka atau diakses melalui web www.geogebra.org kemudian ketik sansania pada kolom pencarian dan buka profil akun tersebut. Pada akun tersebut terdapat beberapa applets yang sudah dikembangkan sebagai bantuan dalam menyelesaikan permasalahan pada LKPD.

Setelah perangkat pembelajaran dikembangkan selanjutnya didiskusikan ke dosen pembimbing dan melakukan revisi sesuai dengan masukan yang diberikan kemudian dilanjutkan dengan validasi.

b. Hasil Validasi Perangkat Pembelajaran

Dua dosen matematika dan guru pelajaran matematika menjadi validator dalam penelitian ini. Dari hasil validasi perangkat pembelajaran diperoleh penilaian dari validator sebagai berikut:

Tabel 5. Hasil Validasi Perangkat Pembelajaran

\begin{tabular}{|c|c|c|}
\hline $\begin{array}{c}\text { Perangkat } \\
\text { Pembelajaran }\end{array}$ & $\boldsymbol{V R}$ & Keterangan \\
\hline Silabus & 3,23 & Valid \\
\hline RPP & 3,43 & Sangat Valid \\
\hline LKPD & 3,22 & Valid \\
\hline
\end{tabular}

Berdasarkan tabel di atas, diperoleh rata-rata total validitas Silabus ( $\left.V R_{\text {Silabus }}\right)$ sebesar 3,23 sehingga Silabus dapat tergolong pada kategori valid. Rata-rata total validitas $\mathrm{RPP}\left(V R_{R P P}\right)$ diperoleh hasil sebesar 3,43 sehingga RPP tergolong pada kategori sangat valid. Sedangkan rata-rata total validitas LKPD $\left(V R_{L K P D}\right)$ diperoleh hasil sebesar 3,22 sehingga LKPD tergolong pada kategori valid. Selanjutnya komentar dari validator terhadap perangkat pembelajaran ini digunakan sebagai masukan untuk melakukan revisi.

Masukan yang diberikan oleh validator terhadap Silabus seperti memperbaiki kalimat pada deskripsi kolom pembelajaran untuk kegiatan mengolah dan mengumpulkan informasi. Selain itu, validator juga menyarankan adanya penambahan mengenai indikator garis singgung persekutuan dua lingkaran. Penambahan indikator ini juga menyebabkan adanya perbaikan pada RPP dan LKPD. Beberapa hal yang di revisi dalam RPP selain indikator adalah penambahan link video motivasi untuk setiap pertemuan ditambahkan pada kegiatan pembelajaran, penambahan materi prasyarat, dan memperbaiki beberapa kalimat pada kolom kegiatan pembelajaran. Selain itu, awalnya RPP disusun untuk 3 kali pertemuan dengan masing-masing pertemuan adalah 2 JP kemudian disarankan oleh guru matematika menjadi 2 pertemuan dengan alokasi waktu pada pertemuan pertama adalah 2 JP dan pertemuan kedua adalah 3 JP. Sedangkan perbaikan pada LKPD seperti pada setiap LKPD di kegiatan "Ayo Bertanya" tidak perlu ditambahkan contoh pertanyaan karena peserta didik dapat mengacu dengan pertanyaan itu saja. Selain itu, perlu ditambahkan screenshoot dari setiap applets GeoGebra ke kegiatan "Ayo Mencoba". Dengan adanya penambahan tampilan ini peserta didik menjadi lebih jelas maksud dari kegiatan yang akan dilakukan. Selanjutnya terdapat beberapa perbaikan pada applets GeoGebra dengan judul garis singgung persekutuan dua lingkaran.

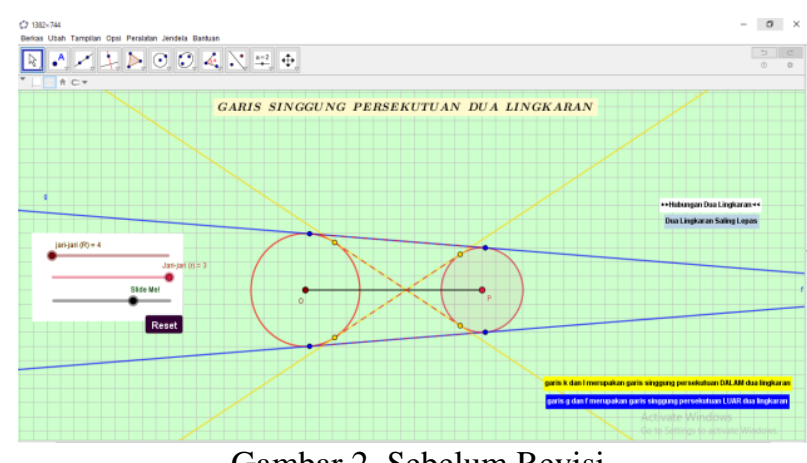

Gambar 2. Sebelum Revisi 


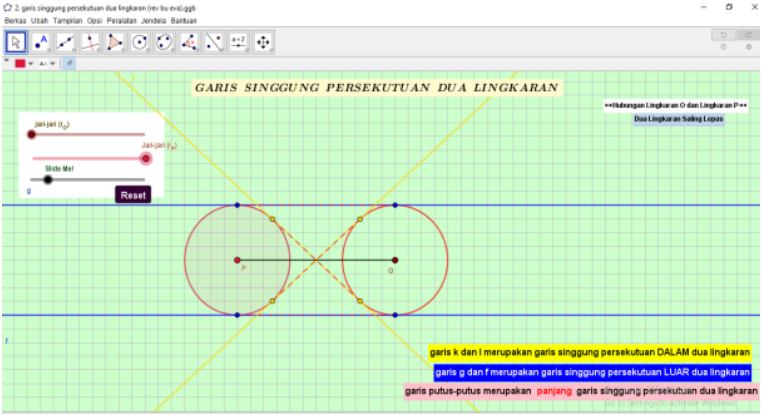

Gambar 3. Hasil Revisi

Saran validator pada applets ini yang pertama adalah pada slider jarak titik pusat antara dua lingkaran dapat ditambahkan pergeseran lingkaran P ke kiri. Jadi, tidak hanya digeser ke kanan saja. Hasil revisi dapat dilihat pada gambar 3 dimana slider slide Me! untuk menggeser titik pusat berada pada sisi kiri dimana kedua lingkaran memiliki jarak yang pendek. Kemudian saran yang kedua, pada bagian garis putusputus sebaiknya diberikan keterangan maksud dari garis putus-putus tersebut hal ini dapat diperhatikan pada gambar 3 bagian keterangan dengan dasar tulisan merah muda. Saran yang ketiga adalah pada slider jarijari lingkaran $O$ dan jari-jari lingkaran $P$ dapat ditambahkan pergeseran ketika jari-jari kedua lingkaran sama.

3. Penilaian

Selanjutnya dilakukan ujicoba perangkat pembelajaran pada subjek yang telah ditentukan yaitu kepada 32 peserta didik kelas VIII-F. Ujicoba ini melibatkan teman sejawat peneliti yang ditugaskan sebagai pelaksana dalam menerapkan perangkat pembelajaran, sedangkan guru matematika dilibatkan untuk mengamati keterlaksanaan pembelajaran. Pengajar menyampaikan informasi awal terlebih dahulu terkait dengan GeoGebra dan cara penggunaanya karena sebelumnya peserta didik belum pernah mengoperasikan program tersebut.

Untuk menilai kepraktisan digunakan data hasil pengamatan keterlaksanaan pembelajaran, berikut disajikan hasilnya:

Tabel 6. Hasil Pengamatan Keterlaksanaan

\begin{tabular}{|c|c|}
\hline Pertemuan & $\begin{array}{c}\text { Rata-rata tiap } \\
\text { pertemuan }\end{array}$ \\
\hline Pertemuan 1 & 3,78 \\
\hline Pertemuan 2 & 3,92 \\
\hline
\end{tabular}

Berdasarkan tabel dapat dilihat untuk pertemuan 1 diperoleh skor sebesar 3,78 kemudian untuk pertemuan 2 adalah 3,92. Maka, dari hasil tersebut pada pertemuan pertama maupun pertemuan dua tergolong kategori sangat baik. Terdapat beberapa komentar yang diberikan guru matematika sebagai pengamat, pada pertemuan satu sebaiknya dituliskan judul yang jelas di papan tulis terkait dengan materi pembelajaran hari ini kemudian ketika menyimpulkan materi di akhir pembelajaran dapat dilakukan secara bersamaan, jadi guru yang bertanya kemudian peserta didik yang lain menjawab bersama-sama. Sedangkan pada pertemuan dua presentasi kelompok dapat diperbanyak lagi, tidak cukup hanya 2 saja karena soal yang diberikan banyak.

Selanjutnya, data hasil tes dan angket respon peserta didik digunakan untuk menilai keefektifan. Analisis hasil tes peserta didik didasarkan pada KKM yang ditetapkan oleh sekolah yaitu 76. Berdasarkan hasil tes tersebut diperoleh bahwa terdapat 27 peserta didik yang tuntas atau lulus dengan nilai $\geq 76$. Sedangkan 5 peserta didik lainnya tidak tuntas dengan nilai $<76$, dikarenakan terdapat soal yang belum terselesaikan karena waktu pengerjaan yang kurang. Persentase ketuntasan klasikal yang diperoleh yaitu sebesar $81,25 \%$, persentase ini menunjukan pada kategori tinggi. Sedangkan hasil respon peserta didik tentang perangka pembelajaran yang dikembangkan diperoleh persentase sebesar $85,2 \%$ yang tergolong pada kategori sangat positif.

\section{Pembahasan}

Berdasarkan hasil penelitian di atas, perangkat pembelajaran yang dikembangkan merupakan perangkat pembelajaran dengan kualitas baik menurut Nieveen (1999) yang memenuhi kriteria valid, praktis dan efektif. Kevalidan Silabus, RPP dan LKPD didasarkan pada hasil validasi dari para validator dengan $V R_{\text {Silabus }}$ sebesar $3,23, V R_{R P P}$ sebesar 3,43 dan $V R_{L K P D}$ sebesar 3,22. Kepraktisan didasarkan pada hasil pengamatan keterlaksanaan, dengan ratarata keterlaksanaan pada pertemuan satu sebesar 3,78 dan untuk pertemuan dua sebesar 3,92 dimana keduanya termasuk pada kategori sangat baik. Sedangkan keefektifan didasarkan pada hasil tes belajar peserta didik pada kategori sangat baik dengan persentase ketuntasan klasikal sebesar $81,25 \%$ dan respon sangat positif oleh peserta didik terhadap perangkat pembelajaran tersebut sebesar $85,2 \%$.

Meskipun perangkat pembelajaran dikatakan valid namun dalam penilaiannya terdapat beberapa nilai 2 dari hasil yang diberikan oleh validator. Penyebabnya adalah karena kurangnya indikator mengenai garis singgung persekutuan dua lingkaran. Hal ini tentunya mempengaruhi tujuan pembelajaran, materi dan juga kegiatan pembelajaran sehingga berpengaruh terhadap nilai yang diberikan. Perbaikan dengan penambahan indikator garis singgung persekutuan dua lingkaran diperlukan karena tidak cukup hanya paham tentang 
pengertian garis singgung lingkaran saja, tetapi juga perlu mengetahui tentang garis singgung persekutuan dua lingkaran. Setelah peserta didik memahami garis singgung persekutuan, barulah peserta didik dapat dikenalkan dengan garis singgung persekutuan luar dua lingkaran dan garis singgung persekutuan dalam dua lingkaran.

Sedangkan hasil dari tes belajar diperoleh peserta didik sebanyak 27 yang tuntas sedangkan sisanya yaitu sebanyak 5 peserta didik dinyatakan tidak tuntas. Hal ini disebabkan karena beberapa alasan yaitu soal belum selesai terjawab karena kehabisan waktu. Penyebab lainnya adalah kendala pada smartphone yang digunakan, hal ini dapat berupa layar yang terlalu kecil sehingga pengerjaan THB menjadi terhambat dan juga terdapat masalah mengenai koneksi dengan internet.

Pengembangan perangkat pembelajaran ini memiliki beberapa perbedaan dengan pengembangan perangkat yang dilakukan oleh Ardiansyah (2018) seperti pembelajaran yang digunakan menggunakan model penemuan terbimbing dan materi yang digunakan adalah geometri pada kelas X. Namun, penelitian ini memiliki kesamaan yaitu menggunakan GeoGebra sebagai alat bantu selama proses pembelajarannya. Hasil penelitian yang dilakukan Ardiansyah menunjukan bahwa perangkat pembelajaran memenuhi kriteria valid, praktis dan efektif. Selain itu penelitian yang telah dilakukan oleh Putri dan Marsigit (2017) memiliki keterkaitan terhadap penelitian ini yaitu menggunakan pendekatan saintifik dan materi yang digunakan pada pokok bahasan yang sama yaitu Lingkaran kelas VIII SMP. Hasil penelitian yang dilakukan Putri dan Marsigit menghasilkan perangkat pembelajaran yang valid, praktis dan efektif. Penelitian-penelitian yang telah dilakukan tersebut memiliki perbedaan dan keterkaitan terhadap penelitian ini. Sebagaimana hasil penelitian terdahulu dapat memperkuat hasil penelitian ini yaitu perangkat pembelajaran yang dikembangkan memenuhi kriteria valid, praktis dan efektif.

\section{PENUTUP}

\section{Simpulan}

1. Proses Pengembangan Perangkat Pembelajaran

Proses pengembangan berdasarkan tahapantahapan pada pengembangan model Plomp (2010) yang terdiri tahap penelitian awal, pembuatan prototipe dan penilaian.

Pada tahap penelitian awal dilakukan analisis kebutuhan peserta didik dan analisis materi seabagai informasi dasar dalam mengembangkan perangkat pembelajaran. Sesuai dengan hasil analisis kebutuhan peserta didik, selama pembelajaran peserta didik belum pernah memanfaatkan media pembelajaran berbasis teknologi. Selain itu, biasanya peserta didik kurang memberikan perhatian jika pembelajaran hanya berpusat pada guru saja sehingga berdampak pada pemahaman peserta didik. Sedangkan analisis materi dilakukan dengan menjabarkan Kompetensi Dasar sehingga diperoleh pokok bahasan hasil penjabaran KD yaitu garis singgung lingkaran, garis singgung persekutuan dan cara melukisnya serta panjang garis singgung persekutuan dua lingkaran.

Pada tahap kedua yaitu pembuatan prototipe dilakukan sesuai dengan pada tahap penelitian awal. Penyusunan Silabus, RPP dan LKPD memuat kegiatan pendekatan saintifik seperti mengamati, menanya, mencoba, mengolah informasi dan mengkomunikasikan. Silabus dan RPP memuat komponen-komponen yang ditetapkan. Kemudian untuk applets GeoGebra disesuaikan dengan pokok bahasan yang telah ditentukan dan dapat diakses melalui akun sansania pada web resmi GeoGebra. Hasil dari perangkat pembelajaran yang telah dikembangkan kemudian didiskusikan terlebih dahulu kepada dosen pembimbing yang kemudian akan divalidasi oleh validator.

Pada tahap terakhir yaitu tahap penilaian ujicoba dilaksanakan kepada subjek yang ditentukan. Selama proses pembelajaran berlangsung, dilakukan pengamatan terkait keterlaksanaan perangkat pembelajaran. Sedangkan pemberian THB dan Angket Respon Peserta didik dilakukan pada pertemuan berikutnya. THB diberikan melalui applets GeoGebra. Hasil tes belajar peserta didik ini kemudian digunakan untuk menentukan keefektifan perangkat pembelajaran. Selain pemberian THB, peserta didik juga diberikan angket respon peserta didik untuk menilai keefektifan perangkat pembelajaran.

2. Hasil Pengembangan Perangkat Pembelajaran

Hasil dari penelitian ini merupakan perangkat pembelajaran menggunakan pendekatan saintifik berbantuan GeoGebra pada materi garis singgung persekutuan dua lingkaran untuk kelas VIII SMP yang memenuhi kriteria valid, praktis dan efektif.

Kevalidan perangkat pembelajaran terpenuhi berdasarkan hasil validasi perangkat pembelajaran dengan $V R_{\text {Silabus }}$ sebesar 3,23 pada kategori valid, $V R_{R P P}$ sebesar 3,43 pada kategori sangat valid dan $V R_{L K P D}$ yaitu sebesar 3,22 pada kategori valid.

Kepraktisan perangkat pembelajaran terpenuhi berdasarkan rata-rata hasil pengamatan keterlakasanaan pada pertemuan pertama yaitu 3,78 sedangkan untuk pertemuan kedua yaitu 3,92. Kedua hasil ini menunjukan pada kategori sangat baik. 
Sedangkan keefektifan perangkat pembelajaran terpenuhi berdasarkan dari hasil tes belajar dan respon peserta didik. Hasil dari tes belajar diperoleh peserta didik sebanyak 27 yang tuntas sedangkan sisanya yaitu sebanyak 5 peserta didik dinyatakan tidak tuntas. Maka, persentase ketuntasan klasikal peserta didik sebesar $81,25 \%$ pada kategori tinggi. Sedangkan respon peserta didik memenuhi kriteria sangat positif yaitu dengan rata-rata sebesar $85,2 \%$.

\section{Saran}

Berdasarkan penelitian yang telah dilakukan, maka terdapat saran yang diberikan peneliti:

1. Hasil dari perangkat pembelajaran yang telah dikembangkan dapat dimanfaatkan sebagai alternatif dalam melaksanakan pembelajaran terkait dengan materi garis singgung persekutuan dua lingkaran.

2. Jika LCD dan proyektor belum tersedia di dalam kelas lebih baik disiapkan sebelum pembelajaran dimulai bersamaan dengan applets GeoGebra yang dibutuhkan dan pastikan bahwa koneksi internet yang digunakan tidak ada masalah sehingga waktu pembelajaran tidak terganggu.

3. Untuk setiap kelompok minimal membawa 2 laptop dengan tujuan jika salah satu laptop bermasalah dapat menggunakan laptop lainnya.

4. Pelaksanaan THB baiknya dilakukan menggunakan laptop karena tampilan yang lebih jelas sehingga mempermudah pengerjaan THB.

\section{DAFTAR PUSTAKA}

Akbar, Sa'dun. 2012. Instrumen Perangkat Pembelajaran. Bandung: Rosda.

Ardiansyah, Ahmad. 2018. Pengembangan Perangkat Pembelajaran Model Penemuan Terbimbing Terintegrasi dengan GeoGebra pada materi pokok Geometri kelas X. MathEdunesa. 1(7):1.

Depdiknas 2003. Kriteria Taraf Keberhasilan. Jakarta: Pusat Perbukuan.

Markus Hohenwarter, et al. 2008. Teaching and Learning Calculus with Free Dynamic Mathematics Software GeoGebra. Dapat diakses pada: https://www.geogebra.org/about

Kemdikbud. 2013. Peraturan Menteri Pendidikan Dan Kebudayaan Republik Indonesia Nomor 81A Tahun 2013 Tentang Implementasi Kurikulum. Jakarta.
Kemdikbud. 2014. Peraturan Menteri Pendidikan Dan Kebudayaan Republik Indonesia Nomor 103 Tahun 2014 Tentang Pembelajaran pada Pendidikan Dasar dan Pendidikan Menengah. Jakarta.

Khabibah, Siti. 2006. Pengembangan Model Pembelajaran Matematika dengan Soal terbuka untuk Meningkatkan Kreativitas Peserta didik SD. Disertasi. Surabaya: Universitas Negeri Surabaya.

Nieveen, N. 1999. Prototyping to Reach Product Quality. London: Kluwer Academic Publisher. Diunduh pada 2 November 2019, dari https://scholar.google.com/citations?user=QzzLN$\underline{\mathrm{kAAAAJ} \& \mathrm{hl}=\mathrm{nl}}$

Maryani, Ika dan Fatmawati. 2015. Pendekatan Scientific dalam Pembelajaran di Sekolah Dasar. Bandung: Deepublish.

Plomp, Tjeerd dan Nieveen, Nienke (Eds.). 2010. An Introduction to Educational Design Research. Enschede: SLO (Netherlands Institute for Curriculum Development)

Pribadi, Benny A. 2017. Media \& Teknologi dalam Pembelajaran. Jakarta: KENCANA.

Putri, Kumala Kusuma dan Marsigit. 2017. Pengembangan Perangkat Pembelajaran Berbasis Pendekatan Saintifik Pada Materi Lingkaran Untuk Meningkatkan Prestasi Belajar Matematika Siswa SMP Kelas VIII. Thesis. Yogyakarta: UNY

Riduwan. 2010. Skala Pengukuran Variabel-variabel Penelitian. Bandung: Alfabeta.

Rusman. 2017. Belajar \& Pembelajaran: Berorientasi Standar Proses Pendidikan. Jakarta: Perenada Media.

Sanjaya, Wina dan Budimanjaya, Andi. 2017. Paradigma Baru Mengajar. Jakarta: KENCANA.

Syahbana, Ali. 2016. Belajar Menguasai GeoGebra. Palembang: NoerFikri Offset.

Widaningsih, Ida. 2019. Strategi dan Inovasi Pembelajaran Bahasa Indonesia di Era Revolusi Industri 4.0. Ponorogo: Uwais Inspirasi Indonesia.

Zuhdan, dkk. 2011. Pengembangan Perangkat Pembelajaran Sains Terpadu Untuk Meningkatkan Kognitif, Keterampilan Proses, Kreativitas serta Menerapkan Konsep Ilmiah Peserta Didik SMP. Program Pascasarjana UNY. 